\title{
TECHNOLOGY OF TEACHING GAME TECHNIQUES IN VOLLEYBALL AT THE STAGE OF INITIAL TRAINING
}

\author{
Eduard Doroshenko $^{1 \mathrm{ABCDE}}$, Olexandr Solovey ${ }^{2 \mathrm{ABCD}}$ and Mykhaylo Melnyk ${ }^{3 \mathrm{ABCD}}$ \\ ${ }^{1}$ Zaporizhzhia State Medical University \\ ${ }^{2}$ Prydniprovska State Academy of Physical Culture and Sports \\ ${ }^{3}$ Volleyball Federation of Ukraine \\ Authors' Contribution: A - Study design; B - Data collection; C - Statistical analysis; D - Manuscript Preparation; E - Funds Collection
}

DOI: $10.17309 / \mathrm{jltm} .2022 .1 .05$

\begin{abstract}
Purpose. To scientifically substantiate the method of teaching game techniques at the stage of initial training to increase the level of technical fitness of young volleyball players.

Materials and methods. The experimental research involved 36 young volleyball players born in 2011 - 18 athletes from the CI "Zaporizhzhia Regional Children and Youth Sports School" of the Zaporizhzhia Regional Council (main group) and 18 athletes from the CI "Vilniansk City Children and Youth Sports School 'Kolos"' (comparison group) during the 2020-2021 academic year.

Results. In the course of experimental research, the indicators of physical fitness of young volleyball players of the main group significantly increased in $80 \%$ of tests. The analysis of technical fitness indicators of young volleyball players of the main group shows that the introduction of the author's method affects their positive dynamics in the tests: consecutive wall passes from a $3 \mathrm{~m}$ distance in $30 \mathrm{~s}$; consecutive overhead passes in $30 \mathrm{~s}$; consecutive forearm passes in $30 \mathrm{~s}$; tennis ball toss over the net to the front line; tennis ball toss over the net to the back line (statistically significant differences, if $\mathrm{p}<0.05)$.

Conclusions. The author's method of teaching game techniques in volleyball is effective and contains the algorithm of teaching, the levels of mastering game techniques, the stages of teaching game techniques, the sequence of teaching game techniques, the classification, occurrence and prevention of young volleyball players' errors in the process of teaching game techniques, differentiation of exercises.

Keywords: volleyball, method, teaching, ability, skill.
\end{abstract}

\section{Introduction}

In the modern theory and methodology of sports training in general, and in volleyball in particular, it is axiomatic that at the stage of initial training of young athletes the leading role is played by the components of teaching motor actions that are directly related to the development of basic knowledge, abilities and skills (Khudolii, Iermakov, \& Bartik, 2020). These components significantly determine the level of proficiency in volleyball techniques, without a successful acquisition of which further quality sports training is practically impossible (Altavilla, 2021).

Modern scientific research highlights various methodological directions regarding the development of game techniques in young volleyball players, which focus on determining and applying the sequence of training, taking into account the age peculiarities of sensory systems functioning

(C) Doroshenko, E., Solovey, O., \& Melnyk, M., 2022.
(Boichuk, Iermakov, Vintoniak, \& Yermakova, 2021); on developing the abilities for spatial and temporal orientation of young volleyball players when performing game techniques, using the extrapolation of motor actions (Boichuk, 2012); on applying anticipation reactions regarding the result of the elementary motor act, which is the basic part of a game technique (Oliinyk, Doroshenko, Melnyk, Sushko, Tyshchenko, \& Shamardin, 2021); comprehensive teaching of game techniques in volleyball, using psychophysiological and physical components (Raiola, Tafuri, \& Lipoma, 2016; Raiola, 2017).

Another promising direction is the comprehensive improvement of teaching game techniques to young volleyball players and developing corresponding motor abilities that determine the effectiveness of their stable performance (Hnatchuk, Lynets, Khimenes, \& Pityn, 2018). In addition, it is effective to use the pedagogical principles of programmed teaching of certain elements of game techniques in volleyball at the stage of initial training (Boichuk, Iermakov, \& Nosko, 2017). 
The studies by Raiola, (2014b); Marchenko and Boiechko, (2018) highlight problematic issues about taking into account sexual dimorphism factors in the process of teaching motor actions, with an emphasis on developing coordination abilities in girls engaged in volleyball. The authors state that the great majority of girls who played volleyball according to the main program had an "average", "below average", and "low" level of coordination abilities and rather low levels of performing the basic game techniques - overhead passes, forearm passes, types of serves, attack and fake hits). Similar tendencies regarding the development of motor qualities during volleyball classes were recorded in experimental studies with girls aged 13-14 (Nešić, Ilić, Majstorović, Grbić, \& Osmankač, 2013) and 15 years (Marchenko \& Dykhanova, 2019).

Also promising are the directions that focus on the use of intensive and extensive means of cognitive orientation in the methodology of teaching game techniques in volleyball. (D'isanto, Altavilla, \& Raiola, 2017) and the formation of appropriate types of feedback based on models of behavior in the "coach - player" system (Giannousi, Mountaki, Karamousalidis, Bebetsos, \& Kioumourtzoglou, 2016). These directions help to significantly intensify the process of teaching game techniques in volleyball and to improve the quality of mastering the basic motor actions. The methodological basis of these directions is the studies (Raiola, 2011; Raiola, 2014a) which analyze the factors of motor control in the process of abilities and skills development in the context of behavioral, cognitive, gestalt-pedagogical, phenomenological theories and the neurophysiological and didactic foundations of their application in physical education and sports.

The direction that is based on the use of active methods of teaching and creating problem situations is close to the above. The study by Renshaw and Chow (2019) shows that such a methodological approach is an effective pedagogical option for teaching voluntary movements in physical education and sports.

The development of a certain abstract model of the future structure of motor activity, including game techniques in volleyball, using logical means, ensures the achievement of predicted states of the athlete's motor function. The studies by Chernenko et al. (2017), Hakman, Nakonechniy, Moseichuk, and Liasota (2017), Samsudin, Setiawan, Taufik, and Solahuddin (2021) show the possibilities of using modeling methods in the process of teaching game techniques in volleyball, based on the material of training sessions with schoolchildren and students. At the same time, of importance are the sequence of applying exercises and their availability in the context of corresponding physical development of young athletes (Forte, D'isanto, Di Domenico, \& Altavilla, 2019) and the current level of athletes' functional fitness as a prerequisite for successful development and further improvement of motor abilities and skills - volleyball game techniques (Maklouf, 2014; Tishchenko, Sokolova, \& Popov, 2019; Shchepotina et al., 2021).

Researchers (Rogal, \& Vaskevych, 2019; Oliynyk \& Doroshenko, 2018) emphasize the importance of developing a positive psychological climate in volleyball teams, which helps increase athletes' motivation to learn and improve the game techniques, and leads to increased efficiency of competitive activities.

The study by Tishchenko and Lysenchuk (2019) focuses on analyzing modern approaches to the development and practical use of innovative technologies for improving special physical and technical-tactical fitness in team sports. The authors emphasize that comprehensive improvement of athletes' special physical and technical fitness is a necessary basis for successful implementation of the process of teaching motor skills and abilities, technical and tactical actions and their combinations, which leads to increased efficiency of the competitive process.

Despite the detailed and thorough study of the problems of teaching motor actions in volleyball, a number of issues regarding the age-related peculiarities of developing athletes' motor function, determination of an optimal sequence of mastering game techniques, integrated development of principal motor qualities and basic game techniques in volleyball are not yet completely solved.

Hypothesis. The introduction of a scientifically grounded method of teaching game techniques at the stage of initial training will help increase the level of technical fitness and efficiency of competitive activities of young volleyball players.

Purpose. To scientifically substantiate the method of teaching game techniques at the stage of initial training to increase the level of technical fitness of young volleyball players.

\section{Material and methods}

\section{Participants}

The experimental research involved 36 young volleyball players born in 2011 - 18 athletes from the CI "Zaporizhzhia Regional Children and Youth Sports School" of the Zaporizhzhia Regional Council (main group) and 18 athletes from the CI "Vilniansk City Children and Youth Sports School "Kolos"' (comparison group).

\section{Organization of the research}

The research was conducted during the 2020-2021 academic year at sports facilities of the Communal Institution "Zaporizhzhia Regional Children and Youth Sports School" of the Zaporizhzhia Regional Council, the Communal Institution "Vilniansk City Children and Youth Sports School 'Kolos", and the Department of Physical Rehabilitation, Sports Medicine, Physical Education and Health of Zaporizhizha State Medical University of the Ministry of Health of Ukraine. The comparison group was trained in accordance with the current volleyball curriculum for children and youth sports schools, specialized children and youth sports schools of the Olympic reserve, sports schools of high sportsmanship, and specialized sports educational institutions (2009). The main group was trained using the developed author's technology for teaching motor actions in volleyball, which contains the following components:

Algorithm of teaching. 1) Building knowledge about the features of a particular game technique (biomechanical and pedagogical analysis of the performance technique). 2) Forming an idea of the performance of a particular game technique, using verbal and nonverbal means, description, visual materials, etc. 3) Developing motor abilities related to a particular game technique. 4) Developing motor skills related to a particular game technique and their improvement.

Levels of mastering game techniques. 1) Developing the abilities and skills of diagnostics and classification of separate 
locomotor acts that are part of the integral game technique. 2) Developing the capability to reproduce the acquired abilities and skills based on understanding of the logic of their internal structure and the athlete's psychophysiological qualities. 3) Developing the capability of the athlete to use the acquired information for implementing motor actions in the training and competitive processes. 4) Developing the capability of the athlete to feel at ease in highly variable competitive situations and make correct decisions concerning the application of variants of game techniques based on the anticipation reaction and its improvement.

Stages of teaching volleyball techniques.

1) Stage of initial learning. The goal is to teach to perform a game technique at the motor ability level.

2) Stage of in-depth learning. The goal is to ensure the performance of game techniques at the motor skill level.

3) Stage of reinforcement and improvement. The goal is to ensure the integral performance of game techniques and their combinations in highly variable conditions of the competitive activity.

Sequence of teaching volleyball techniques.

1) Game stand, moving. 2) Overhead pass. 3) Forearm pass. 4) Serve. 6) Spikes. 7) Blocking. 8) Combinations of game techniques.

Classification, occurrence and prevention of young volleyball players' errors in the process of teaching game techniques.

1) Classification: errors in separate game techniques and common errors; local and complex; typical and atypical; automatic and non-automatic; significant and insignificant. 2) Occurrence: athletes' incorrect understanding of the criteria for performing the game technique; athletes' inability to imaginatively analyze the performance of the game technique; mismatch between the level of intellectual development and muscle sensations; insufficient level of physical fitness; unbalanced development of physical qualities; inappropriate technical means; psychological determinants - uncertainty, hesitancy, etc. 3) Prevention: understanding of the general purpose of teaching game techniques; athletes' understanding of the rational technique of performance; availability of educational materials (intellectual, psychological, physical components); technical specification of game techniques; rational relationship between the speed and accuracy of performing game techniques.
Differentiation of exercises. General development, preliminary, preparatory, special (model).

To determine the effectiveness of the author's method of teaching game techniques, the study conducted pedagogical testing of physical and technical fitness of young volleyball players. The main group included the indicators of 18 young volleyball players of the CI "Zaporizhzhia Regional Children and Youth Sports School" of the Zaporizhzhia Regional Council, the comparison group - the indicators of 18 young volleyball players of the CI "Vilniansk City Children and Youth Sports School 'Kolos"'. During the 2020-2021 academic year, the author's method of teaching volleyball game techniques was introduced into the training process of athletes born in 2011 of the Communal Institution "Zaporizhzhia Regional Children and Youth Sports School" of the Zaporizhzhia Regional Council.

\section{Research methods}

The analysis and generalization of scientific and methodological literature and the Internet materials helped summarize the experience of specialists who studied the problem of developing a method of teaching the elements of volleyball technique. Pedagogical testing was conducted to determine the level of physical and technical fitness of young volleyball players. The pedagogical experiment involved the development of a method of teaching the elements of volleyball technique and experimental verification of its effectiveness.

\section{Statistical analysis}

The obtained indicators were analyzed using the methods of mathematical statistics - determination of the arithmetic mean $(\mathrm{X})$, square deviation $(\mathrm{S})$, percentage value (\%), and statistically significant differences $(\mathrm{p}<0.05)$.

\section{Results}

The results of pedagogical testing of young volleyball players of the main and comparison groups before and after the application of the author's method are presented in Tables 1 and 2.

The analysis of physical fitness indicators of young volleyball players of the main and comparison groups shows

Table 1. Indicators of physical fitness of young volleyball players of the main and comparison groups before and after the pedagogical experiment, $\mathrm{n}=36(\mathrm{X} \pm \mathrm{S})$

\begin{tabular}{|c|c|c|c|c|}
\hline \multirow{3}{*}{ Tests } & \multicolumn{4}{|c|}{ Indicators } \\
\hline & \multicolumn{2}{|c|}{ Main group $(n=18)$} & \multicolumn{2}{|c|}{ Comparison group $(n=18)$} \\
\hline & 09.2020 & 06.2021 & 09.2020 & 06.2021 \\
\hline $20 \mathrm{~m}$ run, $\mathrm{s}$ & $4.61 \pm 0.11$ & $4.32 \pm 0.12^{\star}$ & $4.81 \pm 0.28$ & $4.68 \pm 0.29$ \\
\hline Standing high jump, cm & $26.17 \pm 2.23$ & $31.08 \pm 3.36^{\star}$ & $23.39 \pm 3.41$ & $24.47 \pm 3.57$ \\
\hline Standing long jump, cm & $139.99 \pm 10.08$ & $156.22 \pm 12.28^{*}$ & $141.88 \pm 10.93$ & $142.22 \pm 12.57$ \\
\hline $6 \times 5 \mathrm{~m}$ shuttle run, $\mathrm{s}$ & $11.69 \pm 0.69$ & $10.31 \pm 0.58^{\star}$ & $11.75 \pm 0.79$ & $11.33 \pm 0.88$ \\
\hline \multicolumn{5}{|l|}{$\begin{array}{l}\text { Tossing a medicine ball } \\
\text { weighing } 1 \mathrm{~kg}, \mathrm{~m} \text { : }\end{array}$} \\
\hline sitting & $3.65 \pm 0.68$ & $4.00 \pm 0.74$ & $3.16 \pm 0.50$ & $3.26 \pm 0.49$ \\
\hline standing & $5.69 \pm 1.41$ & $6.73 \pm 1.23^{*}$ & $5.32 \pm 1.01$ & $5.72 \pm 1.34$ \\
\hline jumping & $5.60 \pm 1.21$ & $6.81 \pm 1.34^{*}$ & $5.54 \pm 0.98$ & $5.58 \pm 1.09$ \\
\hline
\end{tabular}

Note: ${ }^{*}$ - statistically significant differences, if $\mathrm{p}<0.05$ 
Table 2. Indicators of technical fitness of young volleyball players of the main and comparison groups before and after the pedagogical experiment, $\mathrm{n}=36(\mathrm{X} \pm \mathrm{S})$

\begin{tabular}{|c|c|c|c|c|}
\hline \multirow{3}{*}{ Tests } & \multicolumn{4}{|c|}{ Indicators } \\
\hline & \multicolumn{2}{|c|}{ Main group $(n=18)$} & \multicolumn{2}{|c|}{ Comparison group $(n=18)$} \\
\hline & 09.2020 & 06.2021 & 09.2020 & 06.2021 \\
\hline $\begin{array}{l}\text { Wall passes from a } 3 \mathrm{~m} \\
\text { distance in } 30 \mathrm{~s}, \mathrm{n}\end{array}$ & $14.44 \pm 2.17$ & $19.79 \pm 2.08^{*}$ & $13.86 \pm 2.77$ & $15.72 \pm 2.45$ \\
\hline Overhead passes in $30 \mathrm{~s}, \mathrm{n}$ & $14.37 \pm 2.23$ & $20.57 \pm 3.11^{\star}$ & $13.11 \pm 3.15$ & $16.85 \pm 3.48$ \\
\hline Forearm passes in $30 \mathrm{~s}, \mathrm{n}$ & $13.31 \pm 2.09$ & $20.12 \pm 3.14^{\star}$ & $2.89 \pm 3.03$ & $15.86 \pm 3.66$ \\
\hline $\begin{array}{l}\text { Tennis ball toss over the net } \\
\text { to the front line, } n\end{array}$ & $4.08 \pm 1.02$ & $6.89 \pm 1.07^{\star}$ & $4.28 \pm 1.07$ & $5.26 \pm 1.44$ \\
\hline $\begin{array}{l}\text { Tennis ball toss over the net } \\
\text { to the back line, } \mathrm{n}\end{array}$ & $5.47 \pm 1.18$ & $8.58 \pm 1.06^{*}$ & $5.34 \pm 1.67$ & $6.33 \pm 1.74$ \\
\hline
\end{tabular}

Note: ${ }^{\star}$ - statistically significant differences, if $\mathrm{p}<0.05$

that the introduction of the author's method has an indirect impact on their positive dynamics (Table 1). At the beginning and end of the 2020-2021 academic year, the indicators of physical fitness of young volleyball players of the main group significantly increased in the following tests: $20 \mathrm{~m}$ run; standing high jump; standing long jump; 6x5 m shuttle run; tossing a medicine ball weighing $1 \mathrm{~kg}$ while standing and jumping $(\mathrm{p}<0.05)$. No statistically significant differences were recorded in the results of tossing a medicine ball weighing $1 \mathrm{~kg}$ while sitting, although there is a linear tendency towards an increase in the results after the introduction of the author's method of teaching volleyball techniques. No statistically significant differences were recorded in the results of physical fitness of young volleyball players of the comparison group, but there is a linear tendency towards an increase in the results in the second testing (at the end of the academic year). In this context, the indicators of physical fitness are considered as a necessary prerequisite for quality acquisition of game techniques in volleyball.

The analysis of technical fitness indicators of young volleyball players of the main and comparison groups shows that the introduction of the author's method directly affects their positive dynamics (Table 2). Pedagogical testing of young volleyball players of the main and comparison groups before and after the introduction of the author's method of teaching game techniques shows that statistically significant differences were recorded in the following tests: consecutive wall passes from a $3 \mathrm{~m}$ distance in $30 \mathrm{~s}$; consecutive overhead passes in $30 \mathrm{~s}$; consecutive forearm passes in $30 \mathrm{~s}$; tennis ball toss over the net to the front line; tennis ball toss over the net to the back line $(p<0.05)$. No statistically significant differences were recorded in the indicators of technical fitness of young volleyball players of the comparison group, although there is also a linear tendency towards an increase in the indicators in the second testing (at the end of the academic year).

\section{Discussion}

The analysis of literary sources and the results of our own research allow us to state that the author's method of teaching game techniques in volleyball occupies a leading place in the educational and training process with young volleyball players (10-11 years old). At the same time, the motor ability in volleyball is considered as a level of performing game techniques based on the detailed conscious control at the main reference points, which is characterized by a low speed of performance, instability of obtained results, low resistance to external factors, and a low level of memorization. The motor skill in volleyball is the next level of performing game techniques. The main differences from the motor ability are the following: minimal participation of consciousness in motor action control at the majority of the main reference points, which indicates the automation of game techniques performance, sufficiently high speed of performance, stability of obtained results, sufficiently high resistance to external factors, and a high level of memorization.

Scientists note that the principal feature distinguishing the motor skill from the motor ability is the automatic nature of separate components and the motor action in general (Boichuk, Iermakov, \& Nosko, 2017). The consistent release of motor action performance from conscious control occurs with the establishment of a specific subordination of control levels in the central nervous system: during motor skill development, lower levels begin to control the processes of muscular and intermuscular coordination. Instead, higher levels ensure the achievement of the motor action goal through the control of its overall sequence.

Another feature of the motor skill is a high speed of motor action performance, which is ensured by a high level of muscular and intermuscular coordination and its general rationality, based on the absence of constraint and ease of elementary motor locomotions (Maklouf, 2014; Forte, D'isanto, Di Domenico, \& Altavilla, 2019).

The stability of obtained results of the action is the third principal feature in the process of developing the motor skill. The motor skill, if it is well developed and improved in the practice of training, practically does not disappear, even during long breaks caused by sports injuries, long illnesses, other factors (Tishchenko, Sokolova, \& Popov, 2019; Shchepotina et al., 2021; Mykhaliuk, Syvolap, \& Horokhovskyi, 2021).

Also important in the process of teaching motor actions is the transfer of learning phenomenon, which is justified from the standpoint of the conditioned-reflex nature of voluntary movements of young volleyball players (Hakman, Osadets, Lymarenko, 2021). From researchers' point of view (Maklouf, 2014), the motor action, the purpose of which is analogous to young volleyball players' past motor experience and contains a corresponding dynamic stereotype, is solved according to a previously formed scheme based on the algorithm of development of a previous motor skill. Re- 
searchers note that the transfer of learning phenomenon is differentiated into negative and positive (Boichuk, Iermakov, \& Nosko, 2017; Altavilla, 2021), which can lead to both deterioration and improvement of the process of motor skills development. At the same time, when teaching game techniques to young volleyball players, it is important to avoid motor skills interference - the transfer of already developed skills to the motor action being studied, which complicates the development of a new skill (Hakman, Osadets, \& Lymarenko, 2021).

It is also important to detailize the process of teaching game techniques in volleyball, which implies a certain stageby-stage approach, namely:

- stage of initial learning of a game technique, which corresponds to the stage of creating prerequisites for mastering the motor act at the motor ability level;

- stage of in-depth detailed learning, which corresponds to the stage of mastering at the motor ability level;

- stage of reinforcement and further improvement of the motor action, which corresponds to the stage of mastering at the skill level.

In addition, some researchers (Platonov, 2017) single out as a separate stage higher order abilities and skills which are used mainly in Olympic and professional sports and are characterized by increased resistance to the influence of external factors in extreme conditions of competitive activities.

\section{Conclusions}

The author's method of teaching game techniques in volleyball is effective and contains the algorithm of teaching, the levels of mastering game techniques, the stages of teaching game techniques, the sequence of teaching game techniques, the classification, occurrence and prevention of young volleyball players' errors in the process of teaching game techniques, differentiation of exercises.

The analysis of technical fitness indicators of young volleyball players of the main group shows that the introduction of the author's method affects their positive dynamics in the tests: consecutive wall passes from a $3 \mathrm{~m}$ distance in $30 \mathrm{~s}$; consecutive overhead passes in $30 \mathrm{~s}$; consecutive forearm passes in $30 \mathrm{~s}$; tennis ball toss over the net to the front line; tennis ball toss over the net to the back line (statistically significant differences, if $\mathrm{p}<0.05)$.

The prospects for further research are based on the importance of optimal determination of reference points when teaching game techniques to young volleyball players and improvement of the author's teaching method in accordance with the age peculiarities of motor abilities and skills development.

\section{Acknowledgement}

The authors thank the administration and the coaching and teaching staff of the Communal Institution "Zaporizhzhia Regional Children and Youth Sports School” of the Zaporizhzhia Regional Council and the Communal Institution "Vilniansk City Children and Youth Sports School 'Kolos"' for practical assistance in conducting experimental research.

\section{Conflict of interest}

The authors declare no conflict of interest.

\section{References}

Khudolii, O., Iermakov, S., \& Bartik, P. (2020). Didactics: methodological basis of motor learning in children and adolescents. Journal of Learning Theory and Methodology, 1(1), 5-13. https://doi.org/10.17309/jltm.2020.1.01

Altavilla, G. (2021). Didactic problem: Teaching and methods in volleyball. Journal of Human Sport and Exercise, 16(4proc): 1698-1704. https://doi.org/10.14198/jhse.2021.16.Proc4.16

Boichuk, R., Iermakov, S., Vintoniak, O., \& Yermakova, T. (2021). Combined impact method in the preparatory period of the annual macrocycle of female volleyball players aged 18-19 years old. Pedagogy of Physical Culture and Sports, 25(4), 234-243.

https://doi.org/10.15561/26649837.2021.0405

Boichuk, R. (2012). Connection of motor memory and success of volleyball game technical elements acquisition by schoolchildren on the lessons of physical education. Teoriâ ta Metodika Fizičnogo Vihovannâ, (12), 6-8. https://tmfv.com.ua/journal/article/view/840

Oliinyk, I., Doroshenko, E., Melnyk, M., Sushko, R., Tyshchenko, V., \& Shamardin, V. (2021). Modern approaches to analysis of technical and tactical actions of skilled volleyball players. Teoriâ ta Metodika Fizičnogo Vihovannâ, 21(3), 235-243. https://doi.org/10.17309/tmfv.2021.3.07

Raiola, G., Tafuri, D., \& Lipoma, M. (2016). Teaching method indication for education and training of sport skills. Mediterranean Journal of Social Sciences, 7(2 S1), 421-424. https://doi.org/10.5901/mjss.2016.v7n2s1p421

Raiola, G. (2017). Motor learning and teaching method. Journal of Physical Education and Sport. 17, 2239-2243. https://doi.org/10.7752/jpes.2017.s5236

Hnatchuk, Ya., Lynets, M., Khimenes, K., \& Pityn, M. (2018). Improvement of physical preparedness of qualified volleyball players. Journal of Physical Education and Sport, 18(1), 239-245. https://doi.org/10.7752/jpes.2018.01032

Boichuk, R., Iermakov, S., \& Nosko, M. (2017). Pedagogical conditions of motor training of junior volleyball players during the initial stage. Journal of Physical Education and Sport, 17(1), 48, 327-334. https://doi.org/10.7752/jpes.2017.01048

Raiola, G. (2014b). Teaching method in young female team of volleyball. Journal of Physical Education and Sport, 14(1), 74-78. https://doi.org/10.7752/jpes.2014.01012

Marchenko, S., \& Boiechko, V. (2018). A study of specific coordination indicators of 11 th grade girls in volleyball training under major program. Teoriâ ta Metodika Fizičnogo Vihovannâ, 18(4), 159-166. https://doi.org/10.17309/tmfv.2018.4.01

Nešić, G., Ilić, D., Majstorović, N., Grbić, V., \& Osmankač, N. (2013). Training effects on general and specific motor skills on female volleyball players 13-14 years old. SportLogia, 9(2), 119-127. https://doi.org/10.5550/sgia.130902.en.007N

Marchenko, S., \& Dykhanova, A. (2019). Motor abilities: peculiarities of effects of volleyball training on 
coordination preparedness of girls aged 15. Teoriâ ta Metodika Fizičnogo Vihovannâ, 19(1), 23-28. https://doi.org/10.17309/tmfv.2019.1.03

D’isanto, T., Altavilla, G., \& Raiola, G. (2017). Teaching method in volleyball service: intensive and exenstive tools in cognitive and ecological approach. Journal of Physical Education and Sport, 17(5), 2222-2227. https://doi.org/10.7752/jpes.2017.s5233

Giannousi, M., Mountaki, F., \& Karamousalidis, G., Bebetsos, G., \& Kioumourtzoglou, E. (2016). Coaching behaviors and the type of feedback they provided to young volleyball athletes. Journal of Physical Education and Sport, 16(2), 1031-1039. https://doi.org/10.7752/jpes.2016.s2164

Raiola, G. (2011). A study on Italian primary school rules: neurophysiological and didatics aspects in physical education and sport. Journal of Physical Education and Sport, 11(2), 43-48. https://efsupit.ro/images/stories/8._Gaetano_Raiola.pdf

Raiola, G. (2014a). Motor control and learning skills according to cognitive and ecological dynamic approach in a vision on behaviorism, cognitive, Gestalt and phenomenology theories. Mediterranean Journal of Social Sciences, 5(15), 504-506. https://doi.org/10.5901/mjss.2014.v5n15p504

Renshaw, I., \& Chow, J.Y. (2019). A constraint-led approach to sport and physical education pedagogy. Physical Education and Sport Pedagogy, 24(2), 103-116. https://doi.org/10.1080/17408989.2018.1552676

Chernenko, S., Malakhova, Z., Timoshenko, V., \& Budyak, L. (2017). Modeling of teaching university students to serve a direct volleyball overhand. Teoriâ ta Metodika Fizičnogo Vihovannâ, 17(2), 55-61. https://doi.org/10.17309/tmfv.2017.2.1189

Hakman, A., Nakonechniy, I., Moseichuk, Yu., \& Liasota, T. (2017). Training methodology and didactic bases of technical movements of 9-11-year-old volleyball players. Journal of Physical Education and Sport, 17(4), 2638-2642. https://doi.org/10.7752/jpes.2017.04302

Samsudin, S., Setiawan, I., Taufik, M., \& Solahuddin, S. (2021). Volleyball fundamental movement learning model in primary school. Teoriâ ta Metodika Fìzičnogo Vihovannâ, 21(3), 194-199. https://doi.org/10.17309/tmfv.2021.3.02

Forte, D., D'isanto, T., Di Domenico, \& Altavilla, G. (2019). Learning the service drills in novice volleyball athletes. Journal of Human Sport and Exercise, 14(Proc5), 24192428. https://doi.org/10.14198/jhse.2019.14.Proc5.57

Maklouf, M. (2014). Osobennosti obucheniya elementam tehniki igryi yunyih voleybolistov. Sportivniy visnik Pridniprovya, 1, 172-176. http://infiz.dp.ua/joomla/media/ sport-visnik-pred/2014-01/2014-01-37.pdf

Tishchenko, V., Sokolova, O., \& Popov, S. (2019). Sovershenstvovanie spetsialnoy fizicheskoy i tehnicheskoy podgotovlennosti voleybolistok vyisokoy kvalifikatsii. Fizichna kultura, sport ta zdorov'ya natsiyi, 8, 218-225. http://eprints.zu.edu.ua/30670/1/218-225.pdf
Shchepotina, N., Kostiukevych, V., Drachuk, A., Vozniuk, T., Asauliuk, I., Dmytrenko, S., Adamchuk, V., Polishchuk, V., Romanenko, I., \& Blazhko, N. (2021). Model morphofunctional characteristics of qualified volleyball players. Sport Mont, 19(S2), 213-217.

Rohal, I.V., \& Vaskevych, S.S. (2019). Metody moralno-volovoi pidhotovky voleibolistiv u ZVO. Naukovyi chasopys [Natsionalnoho pedahohichnoho universytetu imeni MP Drahomanova]. Seriia 15: Naukovo-pedahohichni problemy fizychnoi kultury (fizychna kultura i sport). 6 (114): 64-68. https://spppc.com.ua/index.php/journal/issue/view/7/114pdf

Oliinyk, I., \& Doroshenko, E. (2018). Sotsiometrychni pokaznyky v systemi otsinky psykholohichnoho klimatu voleibolnoi komandy. Sportyvnyi visnyk Prydniprovia. 3, 93-99. http://infiz.dp.ua/miscdocuments/2018-03/2018-03-14.pdf

Tyshchenko, V.O., \& Lysenchuk, H.A. (2019). Analiz suchasnykh pidkhodiv do vykorystannia innovatsiinykh tekhnolohii dlia vdoskonalennia spetsialnoi fizychnoi ta tekhniko-taktychnoi pidhotovky v sporti. Naukovyi chasopys [Natsionalnoho pedahohichnoho universytetu imeni MP Drahomanova]. Seriia 15: Naukovopedahohichni problemy fizychnoi kultury (fizychna kultura i sport), 6(114), 99-104. https://spppc.com.ua/index.php/ journal/issue/view/7/114-pdf

Voleibol: [navchalna prohrama dlia dytiacho-yunatskykh sportyvnykh shkil, spetsializovanykh dytiacho-yunatskykh shkil olimpiiskoho rezervu, shkil vyshchoi sportyvnoi maisternosti ta spetsializovanykh navchalnykh zakladiv sportyvnoho profiliu] (2009) / Turovskyi, V.V., Nosko, M.O., Osadchyi, O.V., Harkusha, S.V., \& Zhula, L.V. K.: Federatsiia voleibolu Ukrainy. 140. http://erpub.chnpu. edu.ua:8080/jspui/handle/123456789/4684

Mykhaliuk, Ye.L., Syvolap, V.V., \& Horokhovskyi, Ye.Yu. (2021). Effect of long-term training on heart rate variability, central hemodynamics and physical working capacity in female swimmers with different sports qualifications. Zaporozhye medical journal, 23(5), 621-627. https://doi.org/10.14739/2310-1210.2021.5.237403

Hakman, A., Osadets, M., \& Lymarenko, H. (2021). Dydaktychni osoblyvosti metodyky navchannia tekhnichnykh dii yunykh voleibolistiv. Naukovyi chasopys [Natsionalnoho pedahohichnoho universytetu imeni MP Drahomanova]. Seriia 15: Naukovo-pedahohichni problemy fizychnoi kultury (fizychna kultura i sport). 6 (137): 46-50. https://doi.org/10.31392/NPU-nc.series15.2021.6(137).11

Platonov, V.N. (2017). Dvigatelnyie kachestva i fizicheskaya podgotovka sportsmenov. K.: Olimpiyskaya literatura. 656. https://www.researchgate.net/publication/323880488_ Dvigatelnye_kacestva_i_fiziceskaa_podgotovka_ sportsmenov 


\title{
ТЕХНОЛОГІЯ НАВЧАННЯ ІГРОВИМ ПРИЙОМАМ У ВОЛЕЙБОЛІ НА ЕТАПІ ПОЧАТКОВОЇ ПІДГОТОВКИ
}

\author{
Едуард Дорошенко ${ }^{1 \mathrm{ABCDE}}$, Олександр Соловей ${ }^{2 \mathrm{ABCD}}$, Михайло Мельник ${ }^{3 \mathrm{ABCD}}$ \\ 13апорізький державний медичний університет \\ ${ }^{2}$ Придніпровська державна академія фізичної культури і спорту \\ ${ }^{3}$ Федерація волейболу України \\ Авторський вклад: А - дизайн дослідження; В - збір даних; C - статаналіз; D - підготовка рукопису; Е - збір коштів \\ Реферат. Статья: 7 с., 2 табл., 32 джерела.
}

Мета - науково обгрунтувати технологію навчання ігровим прийомам на етапі початкової підготовки для підвищення рівня технічної підготовленості юних волейболістів.

Матеріали і методи. В експериментальних дослідженнях брали участь 36 юних волейболістів 2011 року народження - 18 спортсменів КЗ «Запорізька обласна дитячо-юнацька спортивна школа» Запорізької обласної ради (основна група) і 18 спортсменів КУ Вільнянська міська дитячо-юнацька спортивна школа «Колос» (порівняльна група) протягом 2020-2021 навчального року.

Результати. Протягом експериментальних досліджень, показники фізичної підготовленості юних волейболістів основної групи достовірно підвищилися за 80\% тестів. Аналіз показників технічної підготовленості юних волейболістів основної групи свідчить, що впровадження авторської технології має вплив на їх позитивну динаміку за тестами: послідовні передачі м’яча у стінку з відстані 3 м за 30 с; послідовні передачі м'яча двома руками зверху над собою за 30 c; послідовні передачі м'яча двома руками знизу над собою за 30 с; метання тенісного м'яча через сітку на переднюю лінію; метання тенісного м'яча через сітку на задню лінію (статистично достовірні розбіжності, при р $<0,05$ ).

Висновки. Авторська технологія навчання ігровим прийомам у волейболі містить алгоритм навчання, рівні засвоєння ігрових прийомів, етапи навчання прийомам техніки гри, послідовність вивчення прийомів техніки гри, класифікацію, виникнення і попередження помилок, які трапляються у процесі навчання ігровим прийомам у юних волейболістів, диференціацію вправ і є ефективною.

Ключові слова: волейбол, технологія, навчання, уміння, навичка.

\section{Information about the authors:}

Doroshenko Eduard: doroe@ukr.net; https://orcid.org/0000-0001-7624-531X; Zaporizhzhia State Medical University, Department of Physical Rehabilitation, Sports Medicine, Physical Education and Health, Mayakovsky St, 26, Zaporizhzhia, 69035, Ukraine Solovei Oleksandr: 1soloveyaleksandr@gmail.com; https://orcid.org/0000-0002-5713-2480; Pridniprovska State Academy of Physical Culture and Sports, Naberezhna Peremohy St, 10, Dnipro, 49094, Ukraine.

Melnyk Mykhaylo: directorate.fvu@gmail.com; https://orcid.org/0000-0003-4769-7397; Ukrainian Volleyball Federation, p/b B-17, Kyiv, 01001, Ukraine.

Cite this article as: Doroshenko, E., Solovey, O., \& Melnyk, M. (2022). Technology of Teaching Game Techniques in Volleyball at the Stage of Initial Training. Journal of Learning Theory and Methodology, 3(1), 34-40.

https://doi.org/10.17309/jltm.2022.1.05

Received: 12.01.2022. Accepted: 01.02.2022. Published: 28.02.2022

This work is licensed under a Creative Commons Attribution 4.0 International License (http://creativecommons.org/licenses/by/4.0). 